\title{
Epigenetic alterations in preneoplastic and neoplastic lesions of the cervix
}

\author{
Kathleen Saavedra ${ }^{1}$, Priscilla Brebi ${ }^{1}$ and Juan Carlos Roa ${ }^{1,2,3^{*}}$
}

\begin{abstract}
Cervical cancer (CC) is one of the most malignant tumors and the second or third most common type of cancer in women worldwide. The association between human papillomavirus (HPV) and CC is widely known and accepted (99.7\% of cases). At present, the pathogenesis mechanisms of CC are not entirely clear. It has been shown that inactivation of tumor suppressor genes and activation of oncogenes play a significant role in carcinogenesis, caused by the genetic and epigenetic alterations. In the past, it was generally thought that genetic mutation was a key event of tumor pathogenesis, especially somatic mutation of tumor suppressor genes. With deeper understanding of tumors in recent years, increasing evidence has shown that epigenetic silencing of those genes, as a result of aberrant hypermethylation of $\mathrm{CpG}$ islands in promoters and histone modification, is essential to carcinogenesis and metastasis. The term epigenetics refers to heritable changes in gene expression caused by regulation mechanisms, other than changes in DNA sequence. Specific epigenetic processes include DNA methylation, chromotin remodeling, histone modification, and microRNA regulations. These alterations, in combination or individually, make it possible to establish the methylation profiles, histone modification maps, and expression profiles characteristic of this pathology, which become useful tools for screening, early detection, or prognostic markers in cervical cancer. This paper reviews recent epigenetics research progress in the CC study, and tries to depict the relationships between CC and DNA methylation, histone modification, as well as microRNA regulations.
\end{abstract}

Keywords: Cervical cancer, Human papillomavirus, Epigenetics alterations, Biomarkers

\section{Review}

\section{Cervical cancer}

Cervical cancer $(\mathrm{CC})$ is the second most prevalent neoplasia in women worldwide and the fifth cause of death by cancer in this population, posing a significant public health problem [1-3]. The incidence of $\mathrm{CC}$ and its precursor stages is high mainly in developing countries [4]. In 2008 an incidence of 15.8 and a mortality of 8.2 for every 100,000 women was estimated. Around 529,000 new cases are detected every year, with nearly half of these cases dying [5].

The pathogenesis of $\mathrm{CC}$ begins as a slow process that interrupts the normal differentiation of the cervical squamous epithelium, thereby producing changes in its structure and physiology [6]. It initially presents through

\footnotetext{
* Correspondence: jcroa@ufro.cl

'Universidad de La Frontera, School of Medicine, Department of Pathology, Molecular Pathology Laboratory, BIOREN-CEGIN, Temuco, Chile

${ }^{2}$ Pontificia Universidad Católica de Chile, School of Medicine, Department of Pathology, Santiago, Chile

Full list of author information is available at the end of the article
}

precursory lesions that evolve slowly and progressively, which can then advance to slight, moderate, and severe stages of dysplasia. CC may evolve into cancer in situ, which is limited to the epithelial surface, and/or into invasive cancer, in which case the involvement goes beyond the basement membrane [7]. Therefore, one of the characteristic factors of $\mathrm{CC}$ is its defined clinical stages, which are associated with the different evolutionary stages that lead to the development of the carcinogenesis [8].

It has been firmly established, both biologically and epidemiologically, that the main cause of $\mathrm{CC}$ is due to a persistent infection of high-risk human papillomavirus (HPV) types, which are present in $99.7 \%$ of CC cases [9]. Nevertheless, the presence of a persistent high-risk HPV infection risk is not sufficient to immortalize and transform the epithelial cells of the host; it has been confirmed that the presence of genetic and epigenetic alterations are needed for the development of carcinogenesis. As a result, these factors taken together may alter the control of the cell cycle, causing the host cell to

\section{() Biomed Central}


acquire an immortal phenotype and ultimately progress towards a malignant and invasive phenotype [10].

\section{Human papillomavirus}

HPV is a small, non-enveloped virus belonging to the Papillomaviridae family of viruses [11]. It contains a circle of double-stranded DNA approximately $8 \mathrm{~kb}$ in length $[9,12,13]$. Generally, the HPV genome is composed of three basic regions: an early region, composed of six open reading frames (ORFs) known as E1, E2, E4, E5, E6, and E7; a delayed region, with two coding ORFs for the structural viral proteins L1 and L2; and an upstream regulatory region (URR) [14].

The HPV life cycle depends on the replication machinery of the host cell and the differentiation of the squamous epithelium of the cervix $[9,15]$. The cycle begins when infectious viral particles arrive at the basal layer of the epithelium, where they enter the host cell. In the cells of the basal layer of the epithelium, the virus remains stable within an episome with a low number of copies, making up the virus reservoir $[15,16]$. Once the infected cells of the basal layer are divided, some migrate towards the superficial layer, lose their ability to divide, and initiate their terminal differentiation, whereas the others remain in the basal layer, self-renewing the population and maintaining the infection. In the external layers of the epithelium, the viral DNA is packed in capsids and the lineage is released to initiate the infection again (Figure 1) $[9,10,15,16]$.

During the progression of the carcinogenesis, the HPV genome is integrated into the genome of the host cell, so that the virus not only has a complete life cycle but also manages to persist in the host cell. During this integration the coding regions for E1 and E2 are usually interrupted, resulting in the loss of expression from the viral E2 gene, which acts as a repressor of the gene expression of E6 and E7, thus allowing an increase in the expression of both proteins. The form by which E6 and E7 act includes the inactivation of p53 and the hypophosphorylated retinoblastoma protein (pRB), two classic tumor suppressor genes [17]. Currently it is known that E6 and E7 are also linked to various proteins involved in the processes of cell adhesion, including but not limited to apoptosis, cell cycle, DNA repair, metabolism, translation, and transcription signals $[6,12,14,17-19]$.

\section{Epigenetics in CC}

Epigenetics is defined as all those heritable changes in gene expression that cannot be explained by an alteration in the DNA nucleotide sequence [10]. The epigenetic modifications most studied are DNA methylation and histone modification. Recently a new [10] epigenetic phenomenon has been suggested, microRNA (miRNA), which has been implicated in transcriptional silencing $[20,21]$.
A series of epigenetic alterations have been identified that occur during each of the stages of $\mathrm{CC}$, both in the HPV and in the genome of the host cell [10]. One of the earliest pieces of evidence on record with respect to this subject was thanks to a [3 $\mathrm{H}]$-S-adenosylmethionine incorporation assay performed on cervical neoplastic tissue. In this study, it was observed that the degree of hypomethylation (degree of incorporation of the [3 H]methyl group) increased progressively together with the advance of the cervical neoplasia [22]. This finding was confirmed by later studies that involved quantitative analyses of DNA methylation supported by computer analysis on interphase nuclei by immune-labeling with anti-5-methylcytosine antibodies. A progressive demethylation of the tissue was observed in samples of dysplasia and cancer compared to normal controls $[23,24]$.

Indeed, most tumor suppressor genes possess promoter regions rich in $\mathrm{CPG}$ islands, which tend to be hypermethylated in $\mathrm{CC}$, leading to the inactivity of these genes [20].

Identification of numerous epigenetic alterations in all cervical carcinogenesis stages reiterates the potential value of methylation markers for improved diagnosis. Twelve studies have been identified methylation markers in numerous specimens (serum/plasma, liquidbased cytology, cytobrush samples, and urine) of cervical cancer patients. The best performing panel of genes (methylation status for four genes: CALCA, DAPK, ESR1, and APC) was discovered by Wisman et al., in cervical scrapings. Using this mathylation panel a sensitivity of $89 \%$ and a specificity of $100 \%$ was achieved in order to identify cervical cancer patients $[25,26]$.

\section{Methylation in CC}

There are numerous reports demonstrating that abnormal promoter hypermethylation leads to silencing or diminished expression of tumor suppressor genes in cervical carcinoma. Epigenetic silencing due to the methylation of genes involved in different regulatory pathways, such as apoptosis, cell cycle control, and DNA repair, among others, has been widely investigated. What follows is a brief review of the genes described as methylated in cervical carcinogenesis according to the pathway involved [4].

\section{Cell cycle}

It is well established that cancer cells evolve as a result of a deregulation in the normal cell cycle. The adequate regulation of the cell cycle is essential for all cell types and requires a great number of participant molecules, such as cyclin-dependent kinases, along with other natural inhibitors like $\mathrm{p} 16, \mathrm{Rb}$, and $\mathrm{p} 15$, which play an essential role [27]. For its part, high-risk HPV interferes 


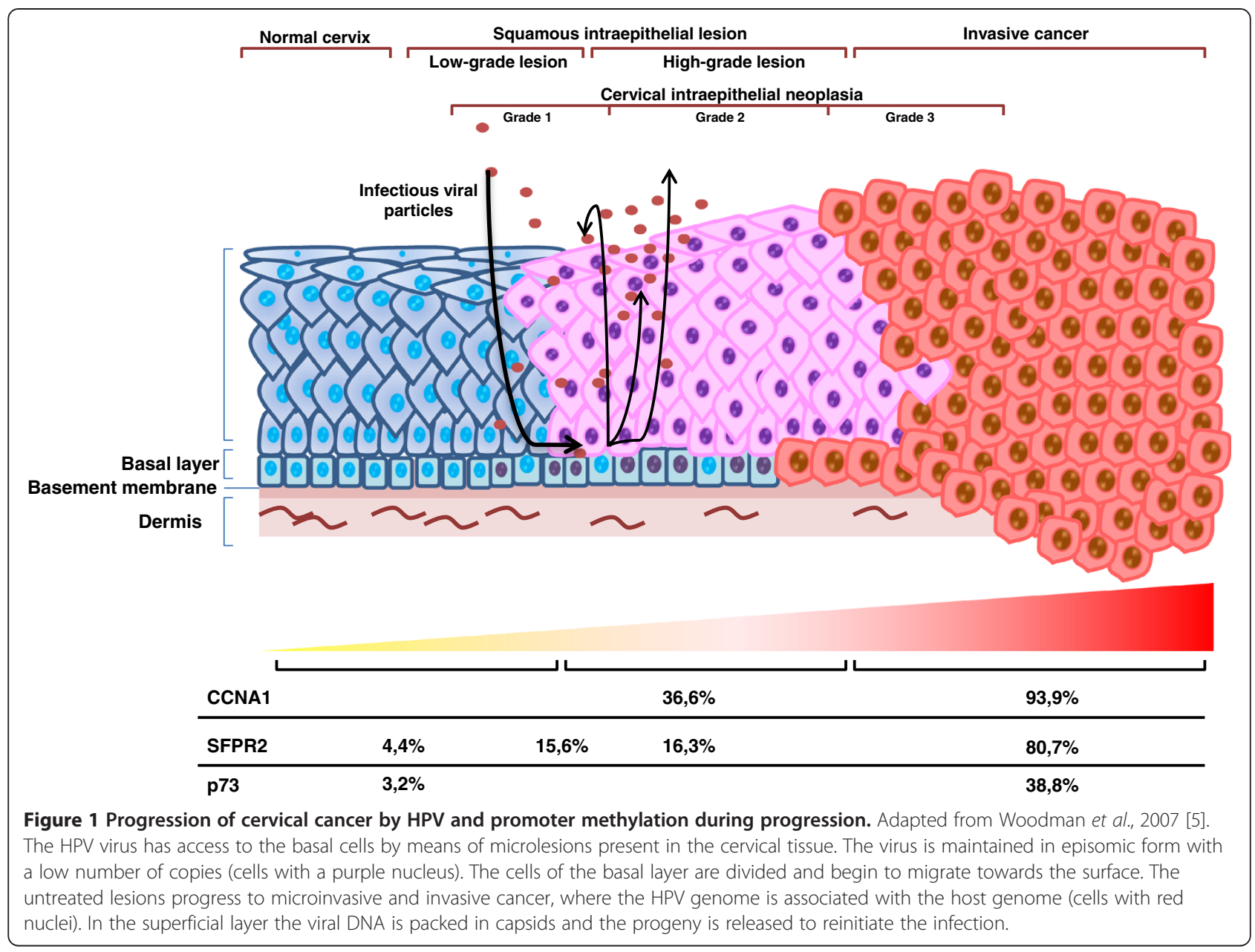

with the control of the normal cell cycle by means of its viral E6 and E7 oncogenes, which have the ability to bind to the regulatory proteins of the host cell, particularly to tumor suppressor genes like p53 and pRB. This event might cause the degradation of p53 on the part of E6 and the inactivation of pRB by binding it to E7 [28], which in turn permits the overexpression of the cyclindependent kinase inhibitor $\mathrm{p} 16\left(\mathrm{p} 16^{\mathrm{INK} 4 \mathrm{~A}}\right)$, leading to genetic instability [29]. p16 ${ }^{\mathrm{INK} 4 \mathrm{~A}}$ (MTS1, CDKN2) encodes a nuclear phosphoprotein involved in the negative regulation of the cell cycle through the inhibition of CDK4 or -6 by binding to the cyclin D1, which regulates the G1 phase of the cell cycle. This mechanism enables the deregulation of pRB1 at the checkpoint of the G1/S phase, thereby affecting cell proliferation $[29,30]$. Accordingly, cases have been reported in which the $\mathrm{p} 16^{\mathrm{INK} 4 \mathrm{~A}}$ protein was found to be strongly expressed in dysplasias and malignant cells of the squamous and glandular epithelium of the cervix [31-33]. It is argued that due to the action of the high-risk HPV viral oncogene $\mathrm{E} 7$ on the $\mathrm{Rb}$ protein, a negative feedback is produced that leads to the overexpression of $\mathrm{p} 16^{\mathrm{INK} 4 \mathrm{~A}}$ $[34,35]$. However, the expression of $\mathrm{p} 16^{\mathrm{INK} 4 \mathrm{~A}}$ in $\mathrm{CC}$ not associated with infection by HPV might be explained by independent pathways of the virus [33]. It has been shown that the inactivation of the tumor suppressor gene $\mathrm{p} 16^{\mathrm{INK} 4 \mathrm{~A}}$ might be mediated by different genetic and epigenetic mechanisms, the latter of which include hypermethylation of the $\mathrm{CpG}$ islands in gene promoter regions; nevertheless, this event is present only infrequently in cases of CC associated with infection by HPV. In these reported cases, it has been observed that the degree of methylation increases as the carcinogenesis progresses $[10,30,33,36]$, being translated in the expression silencing of $\mathrm{p} 16^{\mathrm{INK} 4 \mathrm{~A}}$. This in turn may provoke the binding of the different CDKs involved in the cyclin D1 pathway, leading to the phosphorylation of $\mathrm{Rb}$, this being a key mechanism for releasing the cell cycle from control by $\mathrm{Rb}[14]$.

Cyclin A1 (CCNA1) is a cell cycle regulator essential at the start of metaphase in male meiosis. Thus, a high expression of CCNA1 has been found in testicular cells 
and hematopoietic progenitors; nevertheless, its expression is low in many other types of cells $[37,38]$. Kitkumthorn et al. showed that the CCNA1 promoter region is methylated in cases of $\mathrm{CC}$, and the degree of methylation advances as the oncogenesis progresses. Therefore, in normal samples and in low-grade lesions, no methylation was found; whereas in high-grade lesions, microinvasive cancer, and invasive cancer, 36.6\%, 60\%, and 93.3\%, respectively, were found.

\section{DNA repair}

Silencing of the DNA repair gene $O^{6}$-methylguanine-DNA methyltransferase (MGMT) by methylation of its promoter region is an early event that occurs in various cancers. This gene encodes a DNA repair protein that transfers and accepts alkali groups from the $\mathrm{O}^{6}$ position of the guanine, thereby preventing $G>A$ mutations in the genome [39]. Iliopoulos et al. observed that methylation of this gene increases progressively as the stages of CC advance [40]; similar results were obtained by Lin et al. [33].

In addition to being associated with control of the cell cycle, the CCNA1 gene is also involved in the repair of double-strand DNA breaks affected by radiation [41]. Hypermethylation of the CCNA1 promoter has been associated with a loss of p53 function, which has generally been associated with a degradation resulting from viral oncoprotein E6 [42].

Other genes less frequently related to DNA repair and silenced by methylation of their promoter regions are $h M L H 1$ and FANC [10,43].

\section{Cell differentiation and proliferation}

The Wnt family of proteins involves a wide variety of growth factors that regulate cell differentiation, proliferation, migration, and oncogenesis during embryonic development [44]. It has been shown that the aberrant activation of the Wnt signaling pathway takes place during carcinogenesis, inhibiting the apoptosis of tumor cells in different human cancers. When Wnt ligands are present, they bind to Frizzled (Fz) transmembrane receptors, activating the dishevelled cytoplasmatic protein by phosphorylation. The activation of this protein leads to the activation of the Wnt signaling cascade that culminates in the accumulation of $\beta$-catenin in the cytoplasm. This is deposited in the nucleus, where it forms complexes with members of the TCF/LEF cells and increases the transcription of TCF/LEF-dependent target genes, such as $c-m y c$, cyclin D1, and TCF-1. In normal conditions, that is, in the absence of the carcinogenic process, the family of secreted frizzled-related proteins (SFRPs) is the one responsible for antagonizing the Wnt signaling pathway, among other antagonists. SFRPs bind directly to the Wnt proteins and block their interaction with the Fz transmembrane receptors. As the Wnt signaling pathway is blocked, the intracellular $\beta$-catenin is phosphorylated, ubiquitinated, and finally degraded by proteosomes. Thus, the absence in the nucleus of $\beta$-catenin and TCF/LEF interaction might repress oncogene transcription [45-47]. It has been suggested that the epigenetic silencing of antagonists of the Wnt signaling pathway might result in the aberrant activation of this pathway, leading to carcinogenesis.

\section{Apoptosis}

The apoptosis pathway is interrupted in most human cancers by various phenomena that affect the pathway's main components, as for example the suppression of p14ARF, overexpression of MDM2, or mutation of p53 $[48,49]$.

The p53 pathway responds to stress signals, as they are the interruption in DNA replication fidelity and cell division. These signals activate the p53 pathway specifically by means of post-transcriptional modifications, enabling the arrest of the cell cycle, induction of senescence or cell apoptosis $[48,49]$. One of the protein layers to induce apoptosis is p73, a member of the p53 family of tumor suppressor proteins, a protein with both a strong structural as well as functional homology.

This leads to this protein, when overexpressed, possibly activating the transcription of p53-responsive genes, such as $p 21, B a x, M D M 2$, and GADD45, and to cell growth inhibition by apoptosis induction $[49,50]$. P73 transcription is regulated by promoter regions and the first exon of gene $p 73$, regions rich in $\mathrm{CpG}$ dinucleotides. Methylation in the cytokine residues of $\mathrm{CpG}$ dinucleotides present in these regions plays a key role in the regulation of $p 73$ gene expression due to epigenetic modifications. The transcriptional silencing of $p 73$ has been demonstrated in leukemia, lymphomas, brain tumors, and ovary cell lines [51,52]. Recent studies have reported the existence of epigenetic modifications that might act on $p 73$ through the hypermethylation of their CpG islets, making it an important inactivation mechanism of the gene expression of $p 73$ in CC. In this study it was observed that $38.8 \%$ of samples with CC presented hypermethylation of the $p 73$ gene $v s .3 .2 \%$ in control samples. The hypermethylation of $p 73$ was significantly related to the reduction or suppression of $p 73$ expression. It is important to emphasize that the expression of $p 73$ is associated with favorable responses to radiation therapy in $\mathrm{CC}$, whereas suppression of the protein is related to radioresistance [53].

\section{Histone modification}

Cancer cells show histone modification patterns in individual genes and generally at the nuclear level in individual cells. 
Histone acetyl transferases (HAT) and deacetylases (HDAC) are two enzymes with opposite activities, responsible for regulating the transcriptional machinery, controlling the state of histone acetylation. It has been shown that these enzymes might be involved in cell proliferation, cell differentiation, and regulation of the cell cycle [54-56]. As a result, deregulation of the state of histone acetylation at cell level might be related to the carcinogenic process. In $\mathrm{CC}$ it has been shown that HDAC1 and 2 are overexpressed in cases of dysplasia and CC. The relation that presents the suppression of HDAC2 with the increase of apoptosis, associated with an increase in the p53-independent expression of $\mathrm{p} 21^{\mathrm{Cip} 1 / \mathrm{WAF} 1}$ was also determined [54].

The MGMT gene, the participation of which in DNA repair was detailed previously, is silenced in cases of CC by histone deacetylase action [57]. It has also been reported that the acetylated and phosphorylated forms of histone $\mathrm{H} 3$ in cytological smears display a noticeable association of histone $\mathrm{H} 3$ modification with the progression of carcinogenesis from low-grade to high-grade lesions [58].

It has recently been demonstrated that the therapeutic use of histone deacetylase inhibitors in $\mathrm{CC}$ has a high anti-cancer potential [59].

\section{MiRNA}

Several studies have proven the existence of miRNA expression profiles in cervical cancer. Lee et al. described the overexpression of 10 miRNA in CC: miR199-s, miR-9, miR-199a*, miR-199a, miR-199b, miR-145, miR-133a, miR-133b, miR-214, and miR-127, and only two repressed, miR-149 and miR-203 [60]. More recently Pereira et al. demonstrated that a certain variability exists with respect to the miRNA expression profiles; they described eight miRNA that show a relative reduction in expression during the development of $\mathrm{CC}$, from normal tissue to atypical dysplasia and cancer: miR-26a, miR-143, miR-145, miR-99a, miR-203, miR-513, miR29a, and miR-199a. Nevertheless, they described another six miRNA that showed a drop in expression from the transition from normal tissue to premalignant dysplasia, but that returned to normal levels with the onset of cancer: miR-106a, miR-205, miR-197, miR-16, miR-27a, and miR-142-5p [61].

miR-21 has been described as an oncogene in six types of cancer; in CC it may promote cell proliferation and might repress the expression of programmed cell death 4 (PCD4) [62]. The expression of miR-218 is reduced in $\mathrm{CC}$, its transcriptional target is laminin-5 $\beta 3$ (LAMB3), the expression of which increases in cases of $\mathrm{CC}$, and this has been reported as a marker of invasiveness in cervical lesions (Table 1) [63].
Table 1 miRNA expression in cervical cancer

\begin{tabular}{|c|c|c|}
\hline miRNA & State & References \\
\hline miR-199-s & Overexpressed & {$[60]$} \\
\hline miR-9 & Overexpressed & {$[60]$} \\
\hline miR-199a* & Overexpressed & {$[60]$} \\
\hline miR-199a & $?$ & [66- [61] \\
\hline miR-199b & Overexpressed & {$[60]$} \\
\hline miR-145 & $?$ & [66- [61] \\
\hline miR-133a & Overexpressed & {$[60]$} \\
\hline miR-133b & Overexpressed & {$[60]$} \\
\hline miR-214 & Overexpressed & {$[60]$} \\
\hline miR-127 & Overexpressed & {$[60]$} \\
\hline miR-149 & Repressed & {$[60]$} \\
\hline miR-203 & Repressed & {$[61]$} \\
\hline miR-26a & Repressed & [61] \\
\hline miR-143 & Repressed & [61] \\
\hline miR-99a & Repressed & {$[61]$} \\
\hline miR-513 & Repressed & [61] \\
\hline miR-29a, & Repressed & [61] \\
\hline miR-106a & Repression and subsequent normalization & [61] \\
\hline miR-205 & Repression and subsequent normalization & [61] \\
\hline miR-197 & Repression and subsequent normalization & [61] \\
\hline miR-16 & Repression and subsequent normalization & [61] \\
\hline miR-27a & Repression and subsequent normalization & [61] \\
\hline miR-142-5p & Repression and subsequent normalization & [61] \\
\hline miR-21 & Overexpressed & [62] \\
\hline $\operatorname{miR}-218$ & Repressed & {$[63]$} \\
\hline
\end{tabular}

Thereby, the relationship between cervical carcinogenesis and epigenetics alterations like DNA methylation, histone modifications, and miRNAs have received increasing attention for their potential involvement in the development of $\mathrm{CC}$, especially its usefulness as biomarkers of carcinogenesis. Epigenetic alterations can serve as biomarkers in clinical studies and could be in medical diagnostic. The reversible nature of epigenetic alterations can be considered also for therapeutic approaches of advanced stage cervical cancer.

\section{Conclusions}

In spite of being a relatively new area of study, epigenetic alterations have enabled the understanding of the differences present in the gene expression profiles in different diseases, including carcinogenic processes. This way, these alterations have become a powerful line of investigation for the establishment and progression of cancer. As far as CC is concerned, we can highlight the ample number of genes affected by epigenetic alterations at the level of gene methylation, histone modification, 
and miRNA action. The emergence of this recent information, valuable for the area of clinical diagnosis, has made it possible to establish candidate genes that are useful for the search of early detection biomarkers. Thus the establishment of methylation profiles, histone modification maps, and miRNA expression profiles has become the aim of many investigators, so as to be able to propose new more sensitive and specific alternatives for $\mathrm{CC}$ screening. In the same way, these epigenetic alteration profiles could be used for the prognosis of the disease, for the assessment of the patient's evolution prior to the administration of a certain therapy and for its implementation.

\section{Abbreviations}

CC: Cervical cancer; CCNA1: Cyclin A1; DNTMs: DNA methyltransferase; DKK1: DICKKOPF-1; FHIT: Fragile histidine triad; Fz: Frizzled; HAT: Histone acetyl transferases; HDAC: Histone deacetylases transferases; pRB: Hypophosphorylated retinoblastoma protein; HPV: Human Papilloma Virus; LAMB3: Laminin-5 33 ; MGMT: $0^{6}$-methylguanine-DNA methyltransferase; miRNA: MicroRNA; ORFs: Open reading frames; SFRPs: Secreted frizzled-related proteins; URR: Upstream regulatory region.

\section{Competing interests}

The authors declare that they have no conflicts of interest.

\section{Authors' contributions}

KS designed the article and participated in writing of the manuscript. PB revised the manuscript and contributed to discussion. JCR provided guidance for the overall structure and content of the manuscript. All authors read and approved the final manuscript.

\section{Acknowledgements}

KS, PB, and JR was supported by CORFO, Proyecto Creación del centro de excelencia en estudios genéticos e inmunológicos (CEGIN) 09CN14-5960, Scientific and Technological Bioresource Nucleus (BIOREN); KS is recipient of grants from the Comisión Nacional de Investigación Científica y Tecnológica (CONICYT); PB is recipient of grants from the Fondo Nacional de Desarrollo Científico y Tecnológico (FONDECYT) Proyecto Postdoctorado 3120141 and Fondo de Fomento al Desarrollo Científico y Tecnológico (FONDEF) 3120141. JCR is recipient of grants from FONDECYT 1090171.

\section{Author details}

'Universidad de La Frontera, School of Medicine, Department of Pathology, Molecular Pathology Laboratory, BIOREN-CEGIN, Temuco, Chile. ${ }^{2}$ Pontificia Universidad Católica de Chile, School of Medicine, Department of Pathology, Santiago, Chile. ${ }^{3}$ Department of Pathology, School of Medicine, Universidad de La Frontera, Manuel Montt 112 of 211, Temuco, Chile.

Received: 3 April 2012 Accepted: 26 June 2012

Published: 31 August 2012

\section{References}

1. Munoz N, Bosch FX, de Sanjose S, Herrero R, Castellsaque X, Shah KV, Snijders PJ, Meijer CJ: Epidemiologic classification of human papillomavirus types associated with cervical cancer. N Engl I Med 2003, 348:518-527.

2. Rolon PA, Smith JS, Munoz N, Klug SJ, Herrero R, Bosch X, Llamosas F, Meijer CJ, Walboomers JM: Human papillomavirus infection and invasive cervical cancer in Paraguay. Int I Cancer 2000, 85:486-491.

3. Brebi MP, Ili GC, Lopez MJ, Garcia MP, Melo AA, Montenegro HS, Leal RP, Guzman GP, Roa SJ: Detection and genotyping of human papillomavirus in biopsies of uterine cervical adenocarcinoma. Rev Med Chil 2009, 137:377-382.

4. Lu Q, Ma D, Zhao S: DNA methylation changes in cervical cancers. Methods Mol Biol 2012, 863:155-176.
5. Ferlay JSH, Bray F, Forman D, Mathers C, Parkin DM: GLOBOCAN 2008, Cancer Incidence and Mortality Worldwide: IARC CancerBase No. 10. In Book GLOBOCAN 2008, Cancer Incidence and Mortality Worldwide: IARC CancerBase No. 10. Edited by [Internet]. Lyon: International Agency for Research on Cancer; 2010. Available from: http://globocan.iarc.fr, accessed on 4/04/2012.

6. Woodman CB, Collins SI, Young LS: The natural history of cervical HPV infection: unresolved issues. Nat Rev Cancer 2007, 7:11-22.

7. Salud MD: Guía Clínica Cancer Cervicouterino 2. In Book Guía Clínica Cancer Cervicouterino 2. vol. 1st edition. Edited by Ministerio de Salud. Santiago: Minsal; 2005

8. Schiffman M, Castle PE, Jeronimo J, Rodriguez AC, Wacholder S: Human papillomavirus and cervical cancer. Lancet 2007, 370:890-907.

9. Munoz N, Castellsague X, de Gonzalez AB, Gissmann L: Chapter 1: HPV in the etiology of human cancer. Vaccine 2006, 24(Suppl 3):1-10

10. Szalmas A, Konya J: Epigenetic alterations in cervical carcinogenesis. Semin Cancer Biol 2009, 19:144-152.

11. Shukla S, Bharti AC, Mahata S, Hussain S, Kumar R, Hedau S, Das BC: Infection of human papillomaviruses in cancers of different human organ sites. Indian J Med Res 2009, 130:222-233.

12. Yugawa T, Kiyono T: Molecular mechanisms of cervical carcinogenesis by high-risk human papillomaviruses: novel functions of E6 and E7 oncoproteins. Rev Med Virol 2009, 19:97-113.

13. Nour NM: Cervical cancer: a preventable death. Rev Obstet Gynecol 2009, 2:240-244.

14. Zheng ZM, Baker CC: Papillomavirus genome structure, expression, and post-transcriptional regulation. Front Biosci 2006, 11:2286-2302.

15. Grm HS, Bergant $M$, Banks L: Human papillomavirus infection, cancer \& therapy. Indian J Med Res 2009, 130:277-285.

16. Doorbar J: The papillomavirus life cycle. J Clin Virol 2005, 32(Suppl 1):S7-15.

17. Fernandez AF, Esteller M: Viral epigenomes in human tumorigenesis. Oncogene 2010, 29:1405-1420.

18. McLaughlin-Drubin ME, Munger K: The human papillomavirus E7 oncoprotein. Virology 2009, 384:335-344.

19. Narisawa-Saito M, Kiyono T: Basic mechanisms of high-risk human papillomavirus-induced carcinogenesis: roles of E6 and E7 proteins. Cancer Sci 2007, 98:1505-1511.

20. Duenas-Gonzalez A, Lizano M, Candelaria M, Cetina L, Arce C, Cervera E: Epigenetics of cervical cancer an overview and therapeutic perspectives. Mol Cancer 2005, 4:38.

21. Esteller M: Epigenetics in cancer. N Engl J Med 2008, 358:1148-1159.

22. Kim YI, Giuliano A, Hatch KD, Schneider A, Nour MA, Dallal GE, Selhub J, Mason JB: Global DNA hypomethylation increases progressively in cervical dysplasia and carcinoma. Cancer 1994, 74:893-899.

23. de Capoa AMA, Della RS, Caiafa P, Mariani L, Del Nonno F, Vocaturo A Donnorso RP, Niveleau A, Grappelli C: DNA demethylation is directly related to tumour progression: evidence in normal, pre-malignant and malignant cells from uterine cervix samples. Oncol Rep 2003, 10:545-549.

24. Piyathilake CJ, Celedonio JE, Macaluso M, Bell WC, Azrad M, Grizzle WE: Mandatory fortification with folic acid in the United States is associated with increased expression of DNA methyltransferase-1 in the cervix. Nutrition 2008, 24:94-99.

25. Jones A, Lechner M, Fourkala EO, Kristeleit R, Widschwendter M: Emerging promise of epigenetics and DNA methylation for the diagnosis and management of women's cancers. Epigenomics 2010, 2:9-38

26. Wisman GB, Nijhuis ER, Hoque MO, Reesink-Peters N, Koning AJ, Volders $\mathrm{HH}$, Buikema HJ, Boezen HM, Hollema H, Schuuring E, Sidransky D, van der Zee AG: Assessment of gene promoter hypermethylation for detection of cervical neoplasia. Int J Cancer 2006, 119:1908-1914.

27. Nakashima R, Fujita M, Enomoto T, Haba T, Yoshino K, Wada H, Kurachi $H$, Sasaki M, Wakasa K, Inoue M, Buzard G, Murata Y: Alteration of p16 and p15 genes in human uterine tumours. Br J Cancer 1999, 80:458-467.

28. Munger K, Howley PM: Human papillomavirus immortalization and transformation functions. Virus Res 2002, 89:213-228.

29. Missaoui N, Trabelsi A, Hmissa S, Fontaniere B, Yacoubi MT, Mokni M, Korbi S, Frappart L: p16INK4A overexpression in precancerous and cancerous lesions of the uterine cervix in Tunisian women. Pathol Res Pract 2010, 206:550-555.

30. Semczuk A, Jakowicki JA: Alterations of pRb1-cyclin D1-cdk4/6-p16(INK4A) pathway in endometrial carcinogenesis. Cancer Lett 2004, 203:1-12. 
31. Tringler B, Gup CJ, Singh M, Groshong S, Shroyer AL, Heinz DE, Shroyer KR: Evaluation of p16INK4a and pRb expression in cervical squamous and glandular neoplasia. Hum Pathol 2004, 35:689-696.

32. Reuschenbach $M$, Waterboer $\mathrm{T}$, Wallin $\mathrm{KL}$, Einenkel J, Dillner J, Hamsikova $\mathrm{E}$ Eschenbach D, Zimmer H, Heilig B, Kopitz J, Pawlita M, Doeberitz MK, Wentzensen $\mathrm{N}$ : Characterization of humoral immune responses against p16, p53, HPV16 E6 and HPV16 E7 in patients with HPV-associated cancers. Int J Cancer 2008, 123:2626-2631.

33. Lin Z, Gao M, Zhang X, Kim YS, Lee ES, Kim HK, Kim I: The hypermethylation and protein expression of p16 INK4A and DNA repair gene 06-methylguanine-DNA methyltransferase in various uterine cervical lesions. J Cancer Res Clin Oncol 2005, 131:364-370.

34. Tsoumpou I, Arbyn M, Kyrgiou M, Wentzensen N, Koliopoulos G, Martin-Hirsch P, Malamou-Mitsi V, Paraskevaidis E: p16(INK4a) immunostaining in cytological and histological specimens from the uterine cervix: a systematic review and meta-analysis. Cancer Treat Rev 2009, 35:210-220.

35. Dehn D, Torkko KC, Shroyer KR: Human papillomavirus testing and molecular markers of cervical dysplasia and carcinoma. Cancer 2007, 111:1-14.

36. Gustafson KS, Furth EE, Heitjan DF, Fansler ZB, Clark DP: DNA methylation profiling of cervical squamous intraepithelial lesions using liquid-based cytology specimens: an approach that utilizes receiver-operating characteristic analysis. Cancer 2004, 102:259-268.

37. Baumer N, Sandstede ML, Diederichs S, Kohler G, Readhead C, Ji P, Zhang F, Bulk E, Gromoll J, Berdel WE, et al: Analysis of the genetic interactions between Cyclin A1, Atm and p53 during spermatogenesis. Asian J Androl 2007, 9:739-750

38. Kitkumthorn N, Yanatatsanajit P, Kiatpongsan S, Phokaew C, Triratanachat S, Trivijitsilp P, Termrungruanglert W, Tresukosol D, Niruthisard S, Mutirangura A: Cyclin A1 promoter hypermethylation in human papillomavirusassociated cervical cancer. BMC Cancer 2006, 6:55.

39. Kristensen LS, Nielsen HM, Hager H, Hansen LL: Methylation of MGMT in malignant pleural mesothelioma occurs in a subset of patients and is associated with the T allele of the rs 16906252 MGMT promoter SNP. Lung Cancer 2011, 71:130-136.

40. Iliopoulos D, Oikonomou P, Messinis I, Tsezou A: Correlation of promoter hypermethylation in hTERT, DAPK and MGMT genes with cervical oncogenesis progression. Oncol Rep 2009, 22:199-204.

41. Muller-Tidow C, Ji P, Diederichs S, Potratz J, Baumer N, Kohler G, Cauvet T, Choudary C, van der Meer T, Chan WY, Nieduszynski C, Colledge WH, Carrington M, Koeffler HP, Restle A, Wiesmuller L, Sobczak-Thepot J, Berdel WE, Serve H: The cyclin A1-CDK2 complex regulates DNA double-strand break repair. Mol Cell Biol 2004, 24:8917-8928.

42. Tokumaru Y, Yamashita K, Osada M, Nomoto S, Sun DI, Xiao Y, Hoque MO, Westra WH, Califano JA, Sidransky D: Inverse correlation between cyclin A1 hypermethylation and p53 mutation in head and neck cancer identified by reversal of epigenetic silencing. Cancer Res 2004, 64:59825987.

43. Kang S, Kim JW, Kang GH, Lee S, Park NH, Song YS, Park SY, Kang SB, Lee HP: Comparison of DNA hypermethylation patterns in different types of uterine cancer: cervical squamous cell carcinoma, cervical adenocarcinoma and endometrial adenocarcinoma. Int J Cancer 2006, 118:2168-2171.

44. Cadigan KM, Nusse R: Wnt signaling: a common theme in animal development. Genes Dev 1997, 11:3286-3305.

45. Chung MT, Sytwu HK, Yan MD, Shih YL, Chang CC, Yu MH, Chu TY, Lai HC, Lin YW: Promoter methylation of SFRPs gene family in cervical cancer. Gynecol Oncol 2009, 112:301-306.

46. Lin YW, Chung MT, Lai HC, De Yan M, Shih YL, Chang CC, Yu MH: Methylation analysis of SFRP genes family in cervical adenocarcinoma. $J$ Cancer Res Clin Oncol 2009, 135:1665-1674.

47. Chung MT, Lai HC, Sytwu HK, Yan MD, Shih YL, Chang CC, Yu MH, Liu HS, Chu DW, Lin YW: SFRP1 and SFRP2 suppress the transformation and invasion abilities of cervical cancer cells through Wnt signal pathway. Gynecol Oncol 2009, 112:646-653

48. Vogelstein B, Lane D, Levine AJ: Surfing the p53 network. Nature 2000, 408:307-310.

49. Harris SL, Levine AJ: The p53 pathway: positive and negative feedback loops. Oncogene 2005, 24:2899-2908.

50. Zhu J, Jiang J, Zhou W, Chen X: The potential tumor suppressor p73 differentially regulates cellular p53 target genes. Cancer Res 1998, 58:5061-5065.
51. Martinez-Delgado B, Melendez B, Cuadros M, Jose Garcia M, Nomdedeu J, Rivas C, Fernandez-Piqueras J, Benitez J: Frequent inactivation of the p73 gene by abnormal methylation or LOH in non-Hodgkin's lymphomas. Int J Cancer 2002, 102:15-19.

52. Garcia-Manero G, Bueso-Ramos C, Daniel J, Williamson J, Kantarjian HM, Issa JP: DNA methylation patterns at relapse in adult acute lymphocytic leukemia. Clin Cancer Res 2002, 8:1897-1903.

53. Liu SS, Leung RC, Chan KY, Chiu PM, Cheung AN, Tam KF, Ng TY, Wong LC, Ngan HY: p73 expression is associated with the cellular radiosensitivity in cervical cancer after radiotherapy. Clin Cancer Res 2004, 10:3309-3316.

54. Huang BH, Laban M, Leung CH, Lee L, Lee CK, Salto-Tellez M, Raju GC, Hooi SC: Inhibition of histone deacetylase 2 increases apoptosis and p21Cip1/ WAF1 expression, independent of histone deacetylase 1. Cell Death Differ 2005, 12:395-404.

55. Ellis L, Atadja PW, Johnstone RW: Epigenetics in cancer: targeting chromatin modifications. Mol Cancer Ther 2009, 8:1409-1420

56. Vempati RK, Jayani RS, Notani D, Sengupta A, Galande S, Haldar D: p300 mediated acetylation of histone $\mathrm{H} 3$ lysine 56 functions in DNA damage response in mammals. J Biol Chem 2010, 285:28553-28564.

57. Danam RP, Howell SR, Brent TP, Harris LC: Epigenetic regulation of O6-methylguanine-DNA methyltransferase gene expression by histone acetylation and methyl-CpG binding proteins. Mol Cancer Ther 2005, 4:61-69.

58. Shivapurkar N, Toyooka S, Toyooka KO, Reddy J, Miyajima K, Suzuki M, Shigematsu H, Takahashi T, Parikh G, Pass HI, Chaudhury PM, Gazdar AF: Aberrant methylation of trail decoy receptor genes is frequent in multiple tumor types. Int J Cancer 2004, 109:786-792.

59. Kim IA, Kim IH, Kim HJ, Chie EK, Kim JS: HDAC inhibitor-mediated radiosensitization in human carcinoma cells: a general phenomenon? J Radiat Res (Tokyo) 2010, 51:257-263.

60. Lee JW, Choi CH, Choi JJ, Park YA, Kim SJ, Hwang SY, Kim WY, Kim TJ, Lee $\mathrm{JH}, \mathrm{Kim}$ BG, Bae DS: Altered MicroRNA expression in cervical carcinomas. Clin Cancer Res 2008, 14:2535-2542.

61. Pereira PM, Marques JP, Soares AR, Carreto L, Santos MA: MicroRNA expression variability in human cervical tissues. PLoS One 2010, 5:e11780

62. Yao Q, Xu H, Zhang QQ, Zhou H, Qu LH: MicroRNA-21 promotes cell proliferation and down-regulates the expression of programmed cell death 4 (PDCD4) in HeLa cervical carcinoma cells. Biochem Biophys Res Commun 2009, 388:539-542.

63. Zhou X, Chen X, Hu L, Han S, Qiang F, Wu Y, Pan L, Shen H, Li Y, Hu Z: Polymorphisms involved in the miR-218-LAMB3 pathway and susceptibility of cervical cancer, a case-control study in Chinese women. Gynecol Oncol 2010, 117:287-290.

doi:10.1186/1868-7083-4-13

Cite this article as: Saavedra et al:: Epigenetic alterations in preneoplastic

and neoplastic lesions of the cervix. Clinical Epigenetics 2012 4:13.

\section{Submit your next manuscript to BioMed Central and take full advantage of:}

- Convenient online submission

- Thorough peer review

- No space constraints or color figure charges

- Immediate publication on acceptance

- Inclusion in PubMed, CAS, Scopus and Google Scholar

- Research which is freely available for redistribution 